\title{
THE PROBLEM OF THE RIGHT TO BE FORGOTTEN FROM THE PERSPECTIVE OF SELF-REGULATION IN JOURNALISM
}

\author{
La problemática del derecho al olvido desde la \\ perspectiva de la autorregulación periodística
}

Marina Santín

Nota: Este artículo se puede leer en español en:

http://www.elprofesionaldelainformacion.com/contenidos/2017/mar/17_esp.pdf

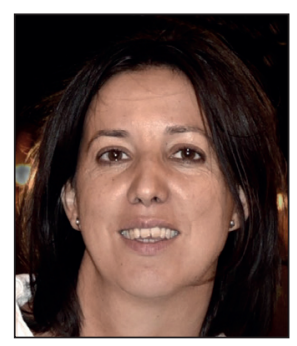

Marina Santín is a lecturer and researcher at the Department of Communication Science and Sociology at the Universidad Rey Juan Carlos (URJC). She has a doctorate in communication and a degree in journalism and law from the Universidad Complutense of Madrid (UCM). Her main area of research is focussed on the analysis of journalistic activity and the application of professional deontology.

http://orcid.org/0000-0002-0036-0861

Universidad Rey Juan Carlos. Facultad de Ciencias de la Comunicación Camino del Molino, s/n. 28943 Fuenlabrada (Madrid), Spain marina.santin@urjc.es

\begin{abstract}
The development of online journalism has facilitated easy access to newspapers' archives by the general public. On occasion this has generated problems for people who have appeared in the news and now have to deal with events from their past life. The management of the right to be forgotten goes beyond the judicial realm, and takes on an ethical component. In this study, we investigate how journalistic institutions act in respect to the right to be forgotten, paying particular attention to those European media which have stated their position regarding the issue. The initiatives are few and the debate appears to have been relegated to an internal problem within each medium.
\end{abstract}

\section{Keywords}

Right to be forgotten; Journalism; Online journalism; Digital press archives; Search engines; Unpublish; Self-regulation; Privacy; Ethics.

\section{Resumen}

El desarrollo del periodismo en la Web ha facilitado el acceso a los archivos de los diarios, generando en ocasiones, a los protagonistas de las noticias la dificultad de superar pasajes de su vida que quedaron reflejados en la prensa. La gestión del derecho al olvido excede al ámbito jurídico y adquiere un componente ético. En este trabajo indagamos en las actuaciones que desde esa perspectiva están llevando a cabo las instituciones periodísticas, prestando atención a aquellos medios europeos de referencia que han fijado públicamente su postura sobre esta materia. Las iniciativas son muy escasas y el debate incipiente parece haber quedado relegado a un problema interno de cada medio.

\section{Palabras clave}

Derecho al olvido; Periodismo; Periodismo digital; Hemerotecas digitales; Buscadores; Despublicar; Autorregulación; Intimidad; Ética.

Santín, Marina (2017). "The problem of the right to be forgotten from the perspective of self-regulation in journalism". El profesional de la información, v. 26, n. 2, pp. 303-310. 


\section{Introduction}

The European Court of Justice (ECJ) ruled in May 2014 regarding the "right to be forgotten", by settling a conflict between Google, the largest internet search engine, the Spanish Data Protection Agency (AEPD), and an individual who wished to delete an embargo notice he had received which had been published in an online daily newspaper, La Vanguardia. The decision was an acknowledgement of the right to be forgotten in Europe; a ruling that citizens under certain circumstances are allowed to hide their data and digital footprint if that information could be deemed damaging or harmful to them ${ }^{1}$. When requesting the deletion of journalistic information, the information about the person must be obsolete and seriously harmful. In addition, the requestor/ affected party must be a person with no public relevance or historic significance.

The ECJ ruling made clear that search engines are responsible for de-indexing the information (and not the media themselves) because the impact on personal privacy of journalistic media articles is lower that the impact caused by the revelation of universal results afforded by a search engine which makes it possible to build up a complete profile of the affected individual. In addition, European authorities decided that search engines deal in data and, consequently, should be responsible for the content they offer. As such, information which is de-indexed in search engines as a result of this ruling will remain in the newspaper's library, although it will become visible/viewable in search engines when the search specifically names the affected party. ${ }^{2}$

Therefore newspapers are, in principle, exempt from the obligation to hide certain information which they have already published if the individuals involved, claiming their right to be forgotten, ask for its "deletion". In fact, the individual who took action against Google also took action against La vanguardia - without success - requesting that La vanguardia withdraw the published news of an embargo against him. From a judicial point of view, and in this precise case, that option was rejected, as the courts ruled that it would be a clear violation of freedom of information and that the right to be forgotten, as with all other rights, is not absolute and must co-exist in harmony with other laws.

\section{Media controversy in light of the European ruling}

Despite the protection that is afforded to digital libraries of journalistic media, the European decision has been controversial and has met with differing opinions in the media. The German daily Der spiegel welcomed the sentence believing that individual's rights should be upheld over the monetary interests of search engines (Der spiegel, 2014).

In Spain, El pais praised the decision claiming that it did not seem logical that in a "democratic society in which even criminal records may be cancelled after a certain period of time, the Internet could become a life sentence for some people" (El país, 2014b).

El mundo deemed that media could not "applaud this decision which affected the right to information so directly" (EI mundo, 2014). In the USA, rejection of the sentence was vir- tually unanimous. The New York Times warned, in its editorial column, that the decision could impede journalists from getting their voice heard and that freedom of the press and freedom of expression would be "undermined" (The New York Times, 2014).

The initial reactions, far from calming the controversy, only served to stir it up. For example, the most significant cases involved the British media. The $B B C$ showed its discontent when a blog article published in 2007, about an ex-director of the investment company Merrill Lynch who had been responsible for a financial scandal, was de-indexed in Google. The author of the story, Robert Peston, wrote an article in which he claimed that the measure infringed upon freedom of expression and that the search engine's de-indexed information was still of interest and should not disappear.

The guardian also showed its disapproval over the removal of several of its own news stories. In the face of these protests, Google rectified and reinstated news stories from The guardian about a Scottish referee who was forced to resign after lying about a penalty, and from the $B B C$ website about Stan O'Neal, the ex-director of the investment company Merrill Lynch.

\section{Despite the protection given to digital libraries of the media, the European de- cision has been controversial and has been met with differing opinions within the media}

While Google, in a show of goodwill, has listened to the media's position and has organized a series of conferences in Europe to debate the best way to put this right into practice, others (Cheshire, 2014; Meyer, 2014) suggest that that the controversial decisions made by Google were, in fact, part of the search engine's strategy to stir up public opinion against the European ruling ${ }^{3}$. While these initial ill-advised actions by Google have led to an increased number of requests, some media, for example the $B B C$ or The telegraph have, since then, have updated their list of all the articles and other content published since that time and subsequently deleted by Google from the results of its searches, in accordance with the EU ruling. The $B B C$ believes that the purpose of this list was to stir up debate about the application of the right to be forgotten by allowing citizens to know what type of article is being deleted by the corporation in compliance with the European sentence.

The media, whether they accept or reject the ruling, agrees on the fact that the application of the ruling will be difficult (El pais, 2014b) and they recognize a need to find a fair balance between public and individual interests (Der spiegel, 2014).

The view from the journalistic profession is that allowing the search engine and its advisers to decide for journalists "would not appear to be the best option" (Lafuente, 2015, p. 97). Also, they warn that there is a chance that by requesting the elimination of a comment from the hundreds which may derive from one piece of information implies an indis- 
criminate deletion of a news story and the resulting comments which appear under the same URL (Lafuente, 2015, p. 98 quoting Pérez Alonso). For Jordan (Jordan, 2014), head of political editing at the $B B C$, the decision to revoke online material should principally be a decision for the editor and, in addition, if this is carried out by the search engine, the media should always be consulted before the link to the news story is removed. Jordan states that they have access to precedents and all the contextual information that is needed to assess the request of the affected individuals.

The idea of greater involvement of the media in the process is preferred by Spanish judicial authorities. In Spain the Supreme Court's first sentence ${ }^{4}$ regarding this law assumed, like the $E C J$, that the digital library cannot be modified nor the news stories deleted and it acknowledged that the right to privacy and respect may clash with the right to information when it is a question of "obsolete and seriously damaging" news stories which make reference to persons of no public relevance or historical interest. But it went one step further by demanding that the media have a more active role in the protection of persons' rights to privacy and respect. In the aforementioned cases the Supreme Courts decided that the right to the protection of personal data justifies requiring the people responsible for newspapers, when so requested by the affected party, to adopt technological measures (such as the use of robots.txt codes or noindex commands) so that the information on digital libraries cannot be reached, in this case, by Internet search engines. In other words, a collaboration is requested from the media group which European authorities, in principle, did not require. However, this does not solve the problem of the role of search engines as actors that decide which news stories to show in search results. Rather, it simply makes it easier for individuals to place claims. If the media hid the information from the search engines it would not be necessary to place a claim on the latter.

\section{The ethical component in the right to be forgotten}

Irrespective of the judicial aspects of the application of the ruling and for which there is an extensive bibliography (Mieres-Mieres, 2014; Martínez-Otero, 2015; Azurmendi, 2015; Boix, 2015; Rustad; Kulevska, 2015), the right to be forgotten and the management of online information opens up other areas of debate. From the journalistic sector, the debate surrounding the deletion of information has an ethical component:

"The inundation of communication media archives on the web has transformed the traditional concept of a media library" (Mieres-Mieres, 2014, p. 31).
So much so that articles and reports which used to have a fleeting public life can now be reactivated at any time and the players may have to relive the past - sometimes perilously - when a news story which involved them in the past, and which they would rather were forgotten or unknown, resurfaces. Whether or not the story is true or of public interest, and irrespective of what might be required of the media source by law, in digital media it is particularly relevant to assess how the passing of time may make self-regulation recommendable in order to restore the balance of the rights in question.

\section{In Europe few media outlets have pu- blished their position regarding the "un- publishing" or "de-indexing" of informa- tion}

The ease with which a person, from anywhere in the world, can access and recover news stories published in a newspaper at some point in its history, and the desire of many citizens to overcome episodes of their lives which have been depicted in the press, means that newspapers are receiving more and more requests from individuals asking for their names to disappear from news stories which appeared in their newspaper. That is what the press ombudsman from the British newspaper The observer, stated when they acknowledged in the annual meeting of the Organization of News Ombudsmen that they spend more and more of their time dealing with this type of requests (Galán, 2015). The newspaper El país, which is a Spanish daily newspaper of reference, also receives such requests, the figure being some 120 requests for information deletion per year ${ }^{5}$. That average is similar to the figure recorded by the British daily 
The guardian (Elliott, 2013). These requests refer not only to factual news stories, but also information which has not been updated or which is erroneous or incomplete. In 2011, the ombudsman for El país went into detail about the different causes that lead citizens to request the deletion of information from the online version of the newspaper stating that, broadly speaking, there are four main scenarios:

- factual news stories regarding behavior or facts which, at the time were considered normal, but the perception of which has changed and is nowadays viewed as negative,

- news stories related to proven criminal activity; the memory of which causes problems of social reinsertion,

- incomplete stories - either because not all details were included or because the story was not investigated properly;

- false or erroneous stories which were not corrected at the time (Pérez-Oliva, 2011).

Even though the right to be forgotten does not legally protect all citizens in their claims against the press and the European ruling has been received in a non-uniform way by the media, it is true that more and more journalists and media (Butterworth, 2007; 2008; English, 2009a; Pérez-Oliva, 2009; Watson, 2012; Elliott, 2013; Lafuente, 2015) are con-

\section{Those media outlets which are blazing a} trail in this area are discovering that they have to position themselves to respond to new situations on a daily basis

sidering how to manage these requests from a deontological perspective.

\section{The journalistic ethic as a solution}

The initial response of the press in general terms was to reject the requests for an "unpublishing" of information; however, over time the press have assumed a more flexible stance. In the Anglo-Saxon world, as a pioneer, it is worth highlighting the work of Kathy English (2009b) of the Toronto star, under the auspices of the Associated Press Managing Editors Online Credibility Project and Ethics and Excellence in Journalism Foundation, which reflect the points of view and praxes of the press in Canada and the USA with regard to this matter. The daily newspapers there, according to English, express a certain reticence to "un-publish" content, but do contemplate certain exceptions (legal or humanitarian reasons, difamatory content...) and almost half of them (49.2\% out of a sample group of 110 editors) have developed a policy to deal with requests for deletion of a news story (p. 6). Managing these requests in a transparent way is of prime importance (English, 2009b, p. 3) and amounts to a

"great challenge for the media but also an opportunity to show their ability to adapt to new demands" (PérezOliva, 2009).

Some institutions, such as The Canadian Association of Journalists, have made some recommendations for adapting to the new demands. In 2010, and following up on the work of
English (2009a), the association passed a series of guidelines to tackle the requests for news deletion received by the media. As a general rule, articles should not be annulled and media should have a clear policy when it comes to requests for "un-publishing"6. This policy should be clearly explained to readers. Although deletion is an exception, it should be remembered that in certain instances, particularly with legal issues, it is an option which should be considered. In other cases, for example where there is remorse on the part of the source or main player in the news story, should be rejected (English; Currie; Link, 2010). In any case, when the "un-publishing" of a news story is carried out, transparency, according to The Canadian Association of Journalists, would dictate that a note should be added to the URL informing readers that the article has been eliminated.

The Canadian association reminds journalists that it is worth pondering long and hard the future implications of an article before going ahead with the publication thereof (English; Currie; Link, 2010). The AEPD has expressed similar concerns and for some years now it has been offering Spanish media a series of considerations. As a preventative measure the AEPD recommends that the press should consider the relevance of publishing the identity of the persons involved in any news story, and in the cases in which naming the person does not add anything significant to the information, it suggests avoiding the use of the identity of the person or using only their initials. Once the information has been published, the $A E P D$ encourages the media to reflect on how advisable it is to maintain permanent access to the news stories which have lost public relevance and/or damaged the privacy of any of the people involved. In addition, it highlights the convenience of

"using computer technology so that, in the case of there being legitimate interest in the individual but the relevance of the event has ceased, the webmaster can prevent the search engines from indexing the news story" (AEPD, Resolución 2010/2012).

It would appear that in Europe few media have published their position regarding the "un-publishing" or "de-indexing" of information?. In Spain it is worth pointing out that the case of El país, which has taken on, in part, the recommendations of the AEPD which were referred to previously. In 2011 it adopted a preventative measure, recommending its journalists omit the name of persons who were not of public relevance if their names were not necessary for the information (Pérez-Oliva, 2011). This measure is not always applied rigorously, judging by the complaints of some readers which have been gathered by the ombudsman for this newspaper (Galán, 2016). More recently, in its 2014 update of the book of style, it assumed most of the other measures. In this way, the paper now has a protocol by which to offer solutions for this problem area in the online environment. It never deletes its digital archives, but it does consider the option of concealing information from the Internet search engines when the news stories in question could harm the claimant in their family or professional life and more than 15 years have passed since the news story was first published (El país, 2014a). In these cases, the decision lies with the newspaper's legal adviser who, under no circumstances, 
considers the claims which refer to "acts which appear in sentences of the courts of justice and refer to acts of violence" (El país, 2014a), thus ruling out remorse in these cases.

In the context of online dailies, it is interesting to highlight the collaboration initiative of librodeestilo.com. This is a project which has been carried out by journalists, university lecturers, and users who have worked together to write up a style manual for what is called "the second generation" for digital media in Spain (Aznar, 2005, p. 133). This book of style has largely been taken on by newspapers such as eldiario.es. It sets out a guideline that, in the event of any errors which affect an entire article it will be "removed from the media's internal search engine and the newspaper will request the removal from Internet search engines." In addition, readers will be told that a deletion has taken place. Notwithstanding the deletion of erroneous news stories, they say that they will only remove information "if to leave it could cause legal or deontological problems". This position is probably too open to tackle such a complex issue as the deletion of news stories.

In the UK it is worth highlighting the position adopted by the The guardian, which has been drawn up its stance over time and, on occasions, adopted innovative positions which have established a trail for other media to follow. The guidelines from the newspaper show that they have been carrying out deletions for legal reasons and when the information which has been published is not accurate and in cases where it can be proved that the person's life or health (mental or physical) would be put at risk by the publication of the information (Elliott, 2013). The guardian considers concealing information involving minors who could be affected by the publication, particularly when the minor cannot give their authorization to appear in a story which, over time, may become uncomfortable for them (Butterworth, 2007). In addition, in some cases in which the source of information has expressed regret over revealing personal experiences and have requested the "un-publishing" of some information, the newspaper has agreed to a much less extreme solution: to substitute the real name of the people involved for a synonym, explaining this change to readers (Butterworth, 2008). This measure was recommended by Reporters Without Borders (2014), after the $E C J$ ruling that upheld the right to be forgotten, as a more appropriate alternative to the deletion of links by the search engines.

The $B B C$ has been highly critical of the European ruling. However, one month after the ruling, it updated its directives regarding the modification or elimination of published content (Jordan, 2014a), favoring self-regulation. The public channel, as has already been mentioned, reckons that the possibility of revo- king news content should be the realm of the media group itself and not external parties (for instance, search engines). On its website there are a series of directives for the removal of online content. As a general rule, unless the content is specifically stated as being available for a limited period of time, it is understood that what has been published is part of an archive which should always be accessible. The threshold for the removal or modification of material from that archive, which has appeared online or on the radio, is very high. It will only be done under exceptional circumstances, for example: for legal reasons; to protect minors; to avoid causing harm or anguish; and, to ensure equality, fairness, and accuracy when dealing with cases. Each request for deletion must be studied in detail and alternatives must be sought to solve the issues raised, before "un-publishing" can be agreed upon. The $B B C$ states that it is transparent with users about any changes or removals which it carries out, unless legal or editorial motives impede.

\section{Deontological essays in the area of "un- publishing"}

The growing debate surrounding the right to be forgotten, as stated by Martínez-Otero,

"will continue to grow for several decades until it takes shape in social practice, jurisprudence, and balanced and fair judicial texts" (Martínez-Otero, 2015, p. 134).

In the field of journalism they have only just begun to write proposals and we have a long way to go. The need to establish a clear policy on the deletion of information in the media is something which not all media have given an answer to or at least not all in the same way. Those media which are blazing a trail in this area, for example, The guardian in the UK or El país in Spain, are discovering that they have to position themselves in response to new situations which are arising on a daily basis.

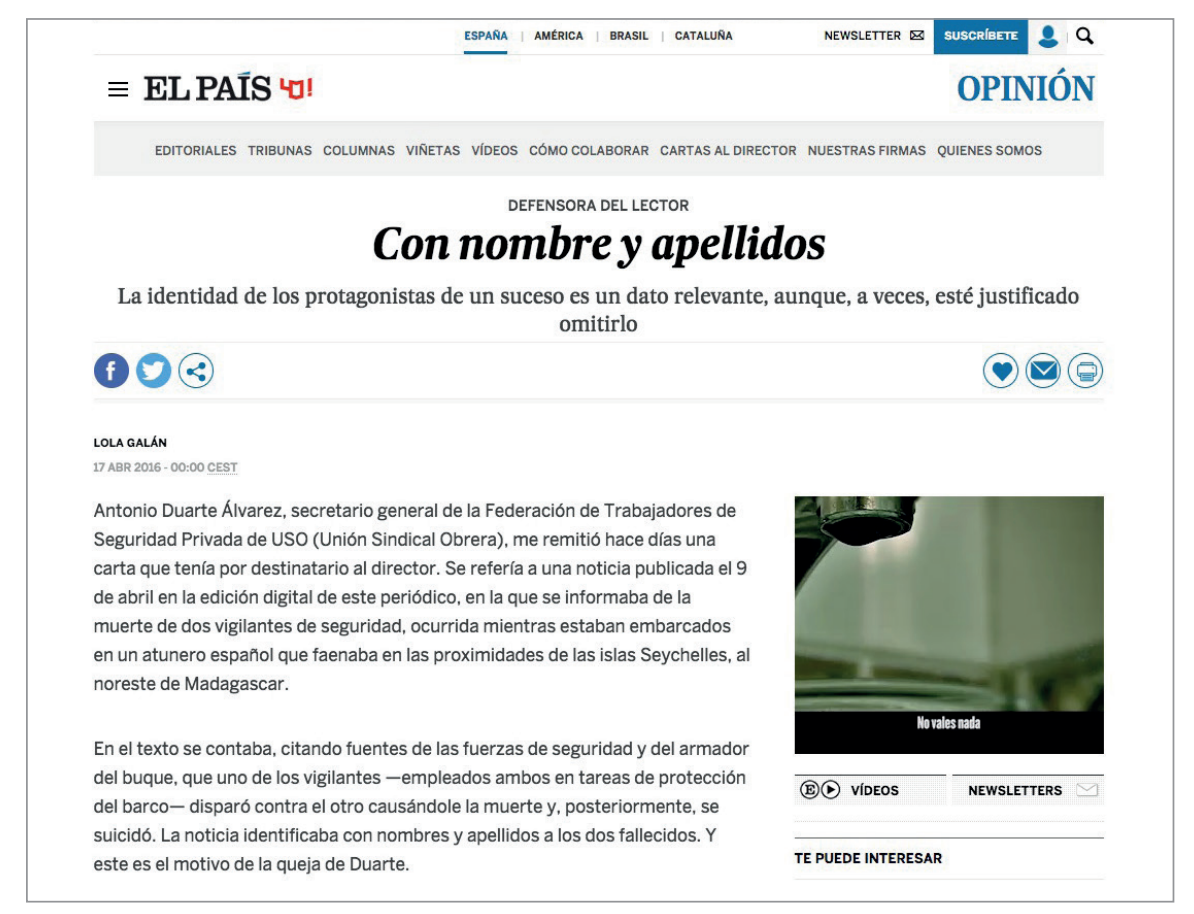

http://elpais.com/elpais/2016/04/15/opinion/1460720001_664306.html 
Regret on the part of the player in the news is one of the issues which has provoked the most debate among the editing teams of the media and over which most discrepancies can be found between the different media groups or journalistic institutions which have taken a clear stand in this area. The difficulty of how to tackle these cases is all the more apparent in the changing policies surrounding the regret of the persons involved and the concealment of their identity, as is the case of The guardian. It has gone from accepting the source's regret (Butterworth, 2008) to rejecting the request for deletion to, finally, studying the possibility of seeing them in a positive light for humanitarian reasons (Elliott, 2013) and opting for anonymity in these cases.

The daily El país is also open to change. This newspaper established its position on this issue in the last edition of its book on style (2014) and recently, in 2016, Alex Grijelmo, who supervises the following editions of this text, considered the convenience of changing the quoted book and including the possibility that in certain cases the names of the people involved in the published news could be deleted to "safeguard the anonymity of women who have suffered abuse and other similar cases" (Grijelmo, quoted in Galán, 2016). He had studied the case of a woman who was the victim of domestic violence, "who appeared in a news story in 1986 and who had chosen to change her name to avoid the stigma which haunted her since the news appeared online" (Galán, 2016).

Despite criticism of the $E C J$ ruling in the media sector, it is worth pointing out that some of the measures the media have taken go beyond what has been established by law

The option of substituting the real name of the affected party for a pseudonym for humanitarian reasons may be the next step for El país in this area; often positions which are announced by the newspaper's ombudsman become the rules for its self-regulation (Santín, 2016, p. 653).

Making progress with this issue is a complex task as it is necessary to possess the technological tools to effectively put the measures into effect (in the case of anonymity, it would be useful to have the option of eliminating the name externally while preserving it internally) and because there are some who feel that any attempts to implement the right to be forgotten are ill-advised and any decision which implies modifying the digital library in any way leads to major controversy.

Irrespective of the deletion or concealing of the news from search engines, but in line with the issue, there are other questions like the follow-up or updating of news ${ }^{8}$ and the correction of errors. Journalistic ethics demands that professionals correct their errors as quickly as possible to reduce any damage which an erroneous or incomplete news story may cause a citizen ${ }^{9}$. The requirement precedes the development of online journalism, but the new technology implies the carrying out of rectifications with even more urgency, as the tools which they use facilitate the constant correction, follow-up, and completion of stories. Several noteworthy initiatives in this area have been documented (Currie, 2014; Mauri-Rios; Ramon-Vegas, 2015).

The media cannot remain aloof about the management of the right to be forgotten; opting for self-regulation on this matter is a good idea

\section{Conclusions}

The media cannot remain aloof to the management of the right to be forgotten and it is advised to opt for self-regulation on this matter. Those media which have opted for this route do not contemplate citizens re-writing the story however they like, but, instead, to make it easier for any who are not in the public eye to exercise their right to be forgotten, thus preventing the journalistic activity from becoming an even greater punishment than a possible judicial sentence.

Journalistic associations should open up a debate to tackle this ever-increasing problem within digital libraries - a debate which takes shape in resolutions which serve as a guideline or a reference for the media. For the moment, the initiatives in this matter are scarce and it is worth pointing out that in North America some journalistic institutions have debated the issue and established guidelines for the management of requests for "un-publishing" news stories and that in Europe, by contrast, this debate is new and has only been considered an internal problem for each media group to deal with. This is probably because they have become absorbed by the conflict caused by European legal treatment of the issue.

Despite criticism of the $E C J$ ruling in the media sector, it is worth pointing out that some of the measures they have taken go beyond what has been established by law. Even though the courts consider it improper to ask the media to eliminate the names and surnames of the persons in the news stories contained in the library, some dailies have considered that option in order to repair the damage which any information may cause to the right to privacy of the people involved.

\section{Notes}

1. The Regulation (EU) 2016/679 of the European Parliament and European Council, of the $27^{\text {th }}$ of April, 2016, relating to individuals and the treatment of personal data and the free movement thereof acknowledges the so-called right to be forgotten in addition to the classic rights to access, rectify, cancel, and object. The right is linked to data protection and the right to information. As regards this association of rights, the Regulation shows that the treatment of personal data with exclusively journalistic ends (in the audiovisual sphere and news archives and libraries) is subject to exceptions, as it is necessary to reconcile the right to data protection with the right to freedom of expression and information.

2. The exercise of the right to cancel and object carried out against search engines only affects the results obtained in 
the search engines using names and surnames. The result which is trying to be hidden will appear on the search engine when the search is carried out using any other word or term other than the name of the affected party.

3. Expert academics, in an open letter to Google, requested greater transparency in the process.

http://www.theguardian.com/technology/2015/may/14/ dear-google-open-letter-from-80-academics-on-right-to-beforgotten

4. The sentence ruled on the request of two individuals asking El país to eliminate a news story from 1985 from their digital library. The story referred to their arrest and imprisonment for drug trafficking and consumption. The people involved had rebuilt their lives and this news story featured high up in the results when carrying out a Google search using the names of the individuals, thus permanently remembering their past.

5. Data supplied by the ombudsman of El país.

6. The word "unpublish" has been coined by AngloSaxon media in particular to describe requests made by individuals for a specific piece of information to be removed from the media's website. The concept of unpublishing is ample and may involve the deletion or the deindexing of the story. The latter option may be carried out by making the story invisible to external search engines (like Google) and/or the internal search engine of the media in particular.

7. In order to develop this piece of work, we contacted the main European daily newspapers to find out the policies that they will put in place to answer the requests for unpublishing. We wrote to the following Spanish dailies: $E I$ país, El mundo and La vanguardia; the French Le monde and Le figaro; the Italian La reppublica and Corriere della sera; the British The times and The guardian and the German Berliner-zeitung, Süddeutsche zeitung and Der spiegel among others. In most cases we did not receive any response. At the same time as we sent the mails, we checked the websites of the media to exam their internal norms or to see if they have an article about how to manage the requests of individuals when claiming the right to be forgotten. It is worth noting that all the ones which have published their position on this issue answered our query. In addition we contacted the Spanish Federation of Journalists Associations (FAPE) and the College of Journalists of Catalonia. This piece of work was carried out based on the answers we obtained and the information which appears on the media websites.

8. The most common cause is that these are people whose names have appeared in stories related to fiscal trials or sentences and who were absolved later but the newspaper has not mentioned that. In such cases, El País includes the new sentence in its online version so that the end of the story is known.

9. This issue is also featured in Spain in the LO2/1984, from the $26^{\text {th }}$ of March, which regulates the right to correction. This is a law which came into effect before the arrival of digital media and which would need to be revised in order to adapt the regulation to the new digital environment.

\section{References}

Aznar, Hugo (2005). Comunicación responsable. La autorregulación en los medios. Barcelona: Ariel. ISBN: 978 8434413061

Azurmendi, Ana (2015). "Por un derecho al olvido para los europeos: aportaciones jurisprudenciales de la Sentencia del Tribunal de Justicia Europeo del caso Google Spain y su recepción por la Sentencia de la Audiencia Nacional española de 29 de diciembre de 2014". Revista de derecho político, n. 92, pp. 273-310.

http://dx.doi.org/10.5944/rdp.92.2015.14428

Boix, Andrés (2015). "El equilibro entre los derechos del artículo 18 de la Constitución, el derecho al olvido y las libertades informativas tras la Sentencia Google". Revista general de derecho administrativo, n. 38, pp. 1-40.

Butterworth, Siobhain (2007). "The readers' editor on... difficult decisions about erasing little bits of history". The guardian, 16 de abril.

https://www.theguardian.com/commentisfree/2007/ apr/16/comment.pressandpublishing

Butterworth, Siobhain (2008). “The readers' editor on... unpublishing". The guardian, 20 de octubre.

https://www.theguardian.com/commentisfree/2008/ oct/20/blogs-publishing-record-privacy

Currie, Tim (2014). "Handling mistakes: Corrections and unpublishing". En: Zion, Lawrie; Craig, David (eds.). Ethics for digital journalists: Emerging best practices, pp.130-144. ISBN: 9780415858847

Cheshire, Tom (2014). "Is Google tryping to make the lasw an ass?". Sky news, 3 July.

http://news.sky.com/story/is-google-trying-to-make-thelaw-an-ass-10398143

Der spiegel (2014). "Europe: 1, Google: 0: EU court ruling a victory for privacy". Spiegel online, 20 May.

http://www.spiegel.de/international/business/court-imposesright-to-be-forgotten-on-google-search-results-a-970419.html

El mundo (2014). Una sentencia peligrosa sobre el 'derecho al olvido' en internet. Editorial El mundo, 14 de mayo de 2014. http://www.elmundo.es/opinion/2014/05/13/53727c4226 8e3e89508b4589.html

El país (2014a). Libro de estilo de El país. Madrid: Aguilar. ISBN: 9788403014480

El país (2014b). "Derecho al olvido”. Editorial El país, 14 de mayo. http://elpais.com/elpais/2014/05/13/opinion/1400007067_055407. html

Elliott, Chris (2013). "The readers' editor on... changing or deleting content in the digital archive". The guardian, 21 July.

https://www.theguardian.com/commentisfree/2013/ jul/21/guardian-readers-editor-digital-archive

English, Kathy (2009a). "Why the Star does not 'unpublish'”. Thestar.com. 31 de enero.

https://www.thestar.com/opinion/2009/01/31/why_the star_does_not_unpublish.html 
English, Kathy (2009b). The longtail of the news: To unpublish or not to unpublish. The Toronto Star, Toronto.

http://c.ymcdn.com/sites/www.apme.com/resource/ resmgr/online_journalism_credibility/long_tail_report.pdf

English, Kathy; Currie, Tim; Link, Rod (2010). "The ethics of unpublishing". Canadian Association of Journalists, 27 Oct. http://www.caj.ca/ethics-of-unpublishing-paper

Galán, Lola (2015). "Tomando el pulso al periodismo en Sudáfrica". El país, 3 de mayo.

http://elpais.com/elpais/2015/05/01/opinion/1430487497_385122. html

Galán, Lola (2016). "Con nombres y apellidos". El país, 17 de abril.

http://elpais.com/elpais/2016/04/15/opinion/1460720001_664306. html

Jordan, David (2014a). "Should the BBC unpublish any of its online content?". About the BBC blogs, 17 June.

http://www.bbc.co.uk/blogs/aboutthebbc/entries/90151d0fae5f-3c11-8ae4-858f67454ed1

Jordan, David (2014b). The sixth public meeting of the Advisory Council to Google on the Right to be Forgotten, in a series of seven across Europe, 16 Oct. 2014, London [Video archive].

https://www.youtube.com/watch?v=9/dOjDyJW24\&feature $=$ youtu. $b e \& t=45 \mathrm{~m} 37 \mathrm{~s}$

Lafuente, Gumersindo (2015). "Por qué es importante para los periodistas preocuparse por el derecho al olvido". Cuadernos de periodistas, n. 30, pp.95-103.

http://www.cuadernosdeperiodistas.com/por-que-esimportante-para-los-periodistas-preocuparse-por-el-llamadoderecho-al-olvido

Martínez-Otero, Juan-María (2015). “El derecho al olvido en internet: debates cerrados y cuestiones abiertas tras la STJUE Google vs AEPD y Mario Costeja". Revista de derecho político, n. 93, pp.103-142.

http://dx.doi.org/10.5944/rdp.93.2015.15139

Mauri-Ríos, Marcel; Ramon-Vegas, Xavier (2015). “Nuevos sistemas de rendición de cuentas de la información periodística. Exploración del escenario online español". El profesional de la información, v. 24, n. 4, pp. 380-389. http://dx.doi.org/10.3145/epi.2015.jul.04

Meyer, David (2014). "Why is Google really removing links to news articles in Europe?". Gigaom, 3 July. https://gigaom.com/2014/07/03/why-is-google-reallyremoving-links-to-news-articles-in-europe

Mieres-Mieres, Luis-Javier (2014). El derecho al olvido. Fundación Alternativas. ISBN: 9788415860259 https://goo.gl/1z8yzB

Parlamento Europeo (2016). "Reglamento (UE) 2016/679 del Parlamento Europeo y del Consejo, de 27 de abril de 2016, relativo a la protección de las personas físicas en lo que respecta al tratamiento de datos personales y a la libre circulación de estos datos y por el que se deroga la Directiva 95/46/CE". Diario oficial de la Unión Europea, 27 abril. http://eur-lex.europa.eu/legal-content/ES/TXT/?uri=uriser v:OJ.L_.2016.119.01.0001.01.SPA\&toc=OJ:L:2016:119:TOC

Pérez-Oliva, Milagros (2009). "Condenados a permanecer en la Red". El país, 22 de marzo.

http://elpais.com/diario/2009/03/22/opinion/1237676405_850215. html

Reporteros Sin Fronteras (2014). Recomendaciones sobre el derecho al olvido, 26 de septiembre.

http://www.rsf-es.org/news/internet-recomendacionessobre-el-derecho-al-olvido

Rustad, Michael L.; Kulevska, Sanna (2015). "Reconceptualizing the right to be forgotten to enable transatlantic data flow". Harvard journal of law and technology, v. 28, n. 2, pp. 348-417 http://ssrn.com/abstract=2627383

Santín, Marina (2016). "Los dilemas éticos del periodismo digital desde la perspectiva de los artículos del defensor del lector de El país". Palabra clave, v. 19, n. 2, pp. 630-659. https://doi.org/10.5294/pacla.2016.19.2.12

The New York Times (2014). "Ordering Google to forget". The opinion pages. Editorial. New York Times, 13 May. http://www.nytimes.com/2014/05/14/opinion/orderinggoogle-to-forget.htm/?_r=0

Tribunal de Justicia de la Unión Europea (2014). Sentencia C-131/12. Google Spain, S.L., Google Inc. / Agencia Española de Protección de Datos, Mario Costeja González. Sentencia de 13 de mayo de 2014.

http://curia.europa.eu/juris/document/document. jsf?docid $=152065$ \&doclang $=E S$

Watson, Dan (2012). "Unpublishing requests are on the rise". Columbia journalism review, 9 April.

http://www.cjr.org/the_news_frontier/unpublishing_ requests_are_on_t.php 